\title{
Why, when, and how to diversify? A comparison between Western theories and the cognition of Chinese enterprises
}

\section{(C) Higher Education Press and Springer-Verlag 2007}

Abstract This paper uses as research samples 140 papers on enterprise diversification published in top-notch Western journals, and public statements from 30 influential contemporary Chinese CEOs on enterprise diversification. Both the qualitative open coding and the qualitative factor analysis are employed to analyze the two samples respectively, and then the corresponding analysis is utilized to explore the differences between Western theories and the cognition of Chinese enterprises on the motivation (why), timing (when) and industry choice (how) of enterprise diversification. Results show that, first, both consider the motivation of diversification mainly from the perspectives of resource-based view and asset portfolio theory. However, Western theories pay more attention to the factors related to the perspectives of the resource-based theory, transaction cost theory and agency theory, while Chinese enterprises put more emphasis on those factors associated with the asset portfolio theory, government policies and institutional theory. Second, on the cognition of the timing of diversification, Western theories insist that enterprises should diversify when they meet threats, while the practice of Chinese enterprises insists that diversification should take place when enterprises have enough strength. Third, Western theories focus more on the interrelationship between the original industry and the intended industry

Translated from Guanli Shijie 管理世界 (Management World), 2005, (8): 94-104

JIA Liangding $(\bowtie)$, QIAN Haiyan, CUI Rongjun

School of Business, Nanjing University, Nanjing 210093, China

E-mail: jldyxlzs@jlonline.com

\section{ZHANG Junjun}

Health Human Resources Development Center, Beijing100009, China

CHEN Yongxia

Jinling School, Nanjing University, Nanjing 210093, China 
than on the attractiveness of the intended industry, while Chinese enterprises pay more attention to attractiveness than interrelationship.

Keywords diversification, motivation, timing, industry choice

\section{Introduction}

The strategy of diversification has been popular in the world since the $1960 \mathrm{~s}$ (Hoskisson and Hitt, 1990: 461). Along with the rapid development of the Chinese economy and enterprises, a lot of Chinese firms have taken the diversification strategy as a means of development since the 1990s. There have been a large number of researches on diversification in the West, but there are few empirical studies in China. Hoskisson and Hitt (1990: 498) provided us with a holistic model of "Diversification Motivations $\rightarrow$ Diversification Strategies $\rightarrow$ Firm's Performance" on the basis of an extensive review on the studies of diversification. If the relationships described in the holistic model are studied in the Chinese context, an interesting question arises-why, when and how to diversify? Are there any difference between the cognition of Western theories and that of Chinese enterprises on the motivation (why), timing (when) and industry choice (how) of enterprises' diversification? In this paper, two samples are selected to seek an exploratory answer to this question. The first one is 140 papers on enterprises' diversification published in top-notch Western journals from 1981 to 2000; the second one is public statements on enterprises' diversification by 30 influential CEOs in China.

\section{A theoretical analysis on the motivation, timing and industry choice of diversification}

\subsection{Motivation of diversification}

Why do firms choose the strategy of diversification? The existing literature gives explanations mainly from the following six perspectives.

Resource-based theory (RBT). Penrose (1995: 24) pointed out that "a firm is more than an administrative unit; it is also a collection of productive resources, the disposal of which between different uses and over time is determined by administrative decision." The optimal growth of the firm involves a balance between the exploration of existing resources and the development of new resources (Wernerfelt, 1984: 172, 178). Developed from the resource theory, the competence theory believes that companies intending on competence leadership tend towards horizontal diversification - around the core competence - rather than towards vertical integration (Hamel, 1994: 30). In empirical researches, 
resources are sorted into tangible resources, intangible resources and financial resources. Both the sharing of tangible resources and the transfer of intangible resources may facilitate diversification (Hoskisson and Hitt, 1990; Chatterjee and Wernerfelt, 1991; Farjoun, 1998; Kochhar and Hitt, 1998).

Transaction Cost Theory (TCT). Williamson (1975) suggested that internal capital markets provide a rationale for diversification. Firms diversify to internalize their assets rather than to sell off their excess assets or to contract for services from markets due to high transaction costs, especially for those much specialized assets and services. Therefore, firms can create an internal capital market with a multi-divisional structure to allocate capital effectively.

Portfolio Theory (PT). The fundamental premise of the portfolio theory suggests that diversified investments balance risks and stabilize revenues. Markham (1973) argued that the total risk, as measured by the variability of consolidated cash flows, is reduced by diversification whenever the respective cash flows of a multi-business firm are not perfectly correlated. Lubatkin and Chatterjee (1994) found that the relationship between corporate diversification and stock return risk generates a U-shaped graph. Thus, an important way for corporations to minimize risks is to diversify into similar businesses rather than into identical or different businesses.

Agency Theory (AT). The agency theory proposes that a utility-maximizing economic agent may take actions that are inconsistent with the interests of the principal (Jensen \& Meckling, 1976). Amihud and Lev (1981) proposed that managers in manager-controlled firms tend to apply policies that distract and reduce risks, although stockholders can diversify on their own in capital markets. The embryonic work of Amihud \& Lev (1981) has been calling for a large number of empirical studies on managerial motives to diversify. The firm's diversification may be due to the managerial consideration of lowering their employment risk and increasing their compensation, rather than objective causes such as resources, market failures, government policies or asset portfolio (Hoskisson and Hitt, 1990; Lane, Cannella and Lubatkin, 1998; Amihud and Lev, 1999; Rose and Shepard, 1997).

Governmental Policy (GP). Anti-trust and tax laws are the main government policies that provide incentives to diversify. Ravenscraf and Scherer (1987) and Markides (1995) showed that the anti-trust constraints on horizontal and vertical mergers had become much stringent and this had resulted in preponderant conglomeration by the 1960s, whereas the constraints were loosened to permit more and larger horizontal mergers in the 1980s and to make refocused mergers and acquisitions prominent. Auerbach and Reishus (1988), and Turk and Baysinger (1989) examined the effects of taxes on diversification from two perspectives - shareholder taxation and corporate taxation. ${ }^{1}$

${ }^{1}$ This analysis was quoted from Hoskisson and Hitt, 1990: 472-473. 
Institutional Theory (IT). It is preferred to explain the firm's diversification in the countries or regions of transitional or emerging economy from the perspective of the institutional theory (Guthrie, 1997; Khanna and Palepu 1997; Li and Wong, 2003; Yao, Lv and Lan, 2004). In these countries or regions, the firm's development largely depends on acquiring resources through non-market mechanisms rather than market mechanisms. Thus, the institutional factors may need to be included when we study the motivation and strategy of diversification of Chinese enterprises.

\subsection{Timing of diversification}

When does a firm diversify? When a firm takes the strategy of diversification, external environments and internal conditions will be evaluated. Such analysis is called the "Strength-Weakness-Opportunity-Threat (SWOT)" analysis (Anthony, 1965; Ansoff, 1965; Andrews, 1971), which is the basic framework of the process of strategic analysis. The firm's operator identifies both opportunities and threats provided by external environments, and finds both strengths and weaknesses through estimating internal conditions. Therefore, to recognize and choose proper timing is an important aspect of the analysis and choice of the strategy of diversification.

\subsection{Industry choice of diversification}

Diversification is a method of the firm's development by entering into different industries, thus industry choice is part of the core of diversification. In most of the literature on diversification, industry choice is considered based on the relationship among industries in which the firm has been engaged. For example, Rumelt (1974) classified the firm's strategy of diversification into four types based on the proportion of every single business to its revenues. The four types are single business, dominant business, related business and unrelated business. Another method to estimate the business relatedness includes the use of the Standard Industry Classification (SIC) codes. For example, the method of business relatedness measurement in Simmonds (1990) is as follows. Each four-digit SIC code defines a unique business, and all the other businesses with the same first two digits of the SIC code are deemed related.

Porter (1985: 376) suggested that the presence of the interrelationship per se is not sufficient justification for entering an industry unless they allow a firm to transform an unattractive industry into an attractive one. Thus, seeking industries with both an attractive structure and the interrelationship that will yield a competitive advantage in those industries are the twin keys to the strategy of diversification. There are three types of interrelationships, which are tangible, 
intangible and competitor interrelationships. Including procurement, technology, infrastructure, production, and market interrelationships, the tangible interrelationship arises from opportunities to share activities in the value chain among related business units, due to the presence of common buyers, channels, technologies, and other factors (Porter, 1985: 324). The intangible interrelationship involves the transference of management experience and skills among separate value chains. Businesses that cannot share activities may nevertheless be similar in generic terms, such as the type of buyer, type of purchase, type of manufacturing process employed and type of relationship with the government (Porter, 1985: 324). The competitor interrelationship stems from the existence of rivals that actually or potentially compete with a firm in more than one industry (Porter, 1985: 325). The state of competition in an industry depends on five basic competitive forces, which are potential entrants, substitute producers, suppliers, buyers and current competitors. The collective strength of these forces determines the ultimate profit and the potential of the firm in the industry, and thus the industrial attractiveness (Porter, 1980: 6), which includes the potential of the profit and market in the industry, the entry and exit barriers of the industry, the fixed costs and storage costs, government policies and so on.

\section{Research samples}

\subsection{Sample I}

The 140 papers on firms' diversification published in 10 of the top management and economics journals including Strategic Management Journal, Academy of Management Journal, etc., from 1981 to 2000 (See Appendix 1), served as Sample I. About $80 \%$ of the papers were from SMJ and $A M J$ (See Table 1), and most of the papers appeared during the period from 1986 to 2000 (See Table 2). The research group studied each of the 140 papers and extracted the discussions

Table 1 Sources of the 140 papers (Sample I)

\begin{tabular}{lcccccccccc}
\hline Sources of papers & $S M J$ & $A M J$ & $J M$ & $J M S$ & $H B R$ & $A M R$ & $O S$ & $A M E$ & $M S$ & $R J E$ \\
\hline Number of papers & 90 & 21 & 9 & 6 & 5 & 3 & 3 & 1 & 1 & 1 \\
\hline
\end{tabular}

Table 2 Year of publication of the 140 papers (Sample I)

\begin{tabular}{lcccc}
\hline Year of publication & $1981-1985$ & $1986-1990$ & $1991-1995$ & $1996-2000$ \\
\hline Number of papers & 8 & 49 & 45 & 37 \\
\hline
\end{tabular}

Note: One more paper is from SMJ in 2004. 
on the motivation, timing, and industry choice of diversification from them. We obtained 18,000-word coding data in English for further coding.

\subsection{Sample II}

The public statements on diversification of 30 influential Chinese CEOs, such as Zhang Ruimin (Haier), Liu Chuanzhi (Lenovo), Tao Jianxing (Chunlan), Zong Qinghou (Wahaha), Lu Guanqiu (Wanxiang), Ren Zhengfei (Huawei) and Duan Yongping (Bubugao), were chosen as the second research sample. The average age of these CEOs is 51. They became CEOs of the firms around 1989. In the last three years, the average sales of the 30 companies were 17.4 billion RMB. Most of the 30 companies are private and located in coastal areas and engaged in manufacturing, communications and high technology industries (See Table 3(a)).

Table 3(a) Descriptions of the companies managed by the 30 CEOs (Sample II)

\begin{tabular}{llrr||lllr}
\hline & & Freq. & $\%$ & & & Freq. & $\%$ \\
\hline Ownership & Private & 25 & 83.3 & The & Guangdong & 6 & 20.0 \\
& Collective & 3 & 10.0 & province & Zhejiang & 6 & 20.0 \\
& State-owned & 2 & 6.7 & / city & Beijing & 5 & 16.7 \\
& Total & 30 & 100.0 & where & Shanghai & 3 & 10.0 \\
Industry & Manufacturing & 19 & 63.3 & HQ & Jiangsu & 2 & 6.7 \\
& Telecommunications/ & 8 & 26.7 & locates & Shandong & 2 & 6.7 \\
& High technology & & & & Shanxi & 2 & 6.7 \\
& Real estate/ & 3 & 10.0 & & Others & 4 & 13.2 \\
& Construction & & & & Total & 30 & 100.0 \\
& Total & 30 & 100.0 & & & & \\
\hline
\end{tabular}

Table 3(b) Descriptions of the CEOs and their companies (Sample II)

\begin{tabular}{lccccc}
\hline & $N$ & Min & Max & Mean & Standard deviation \\
\hline Age (in 2005) & 30 & 37.00 & 68.00 & 50.97 & 8.985 \\
Years of founding the firm & 30 & 1969 & 2001 & 1989 & 6.641 \\
Sales (hundred million Yuan) & 25 & 5.00 & 1000.00 & 173.79 & 235.43 \\
\hline
\end{tabular}

Note: The sales of only 25 firms were obtained, among which 6 are the sales of 2002, 3 are those of 2003, and 16 are those of 2004.

The public statements of the 30 CEOs on diversification since 2000 were collected. They were either in the form of interviews with the CEOs or articles or speeches by the CEOs. After collecting the public statements, 150 pages of about-218,500-character data in Chinese were obtained for further coding. The 
average number of characters in each CEO's data was 7,283, which ranged from 628 to 20,000 (See Table 3(b)).

\section{Research methods and procedures}

The qualitative open coding was employed in the data of the three samples to encode the motivation, timing and industry choice of diversification. After the qualitative open coding was finished, the qualitative factor analysis was utilized on the coding results for item reduction and structure identification.

\subsection{Qualitative open coding}

Coding is the analytic process through which data are fractured, conceptualized, and integrated to form theories (Strauss \& Corbin, 1998: 3). Qualitative coding means creating categories from the interpretation of data (Goulding, 2002: 76). Open coding is the analytic process through which concepts are identified and their properties and dimensions are discovered in data (Strauss and Corbin, 1998: 101). In this paper, the qualitative open coding is employed, which has three characteristics. First, it doesn't require preconceived theoretical structures; second, the data need not be quantified; third, the concepts are identified and their properties and dimensions are discovered in the data. Two coding methods are used in this study - coding line-by-line and coding by analyzing a whole sentence or paragraph (Strauss and Corbin, 1998: 119-120).

The data of the two samples on the motivation, timing and industry choice of diversification were coded in double-blind fashion by three authors. The requirements of coding were as follows. For the data of Sample I, i.e., the 140 papers, the same viewpoints put forward by the same author in each paper were coded only once; for the data of Sample II, i.e., the 30 CEOs' public statements, the same viewpoints that appeared in the same case were coded only once. After the coding, the results were summarized, then the research head discussed them with the three coders item by item. The agreement rates of coding before discussion are presented in Table 4 . The sums of the three-coder-agreement rate and the two-coder-agreement rate exceed $60 \%$ except those of the timing and industry choice coding of the 140 papers (the sum of the three-coder-agreement rate and the two-coder-agreement rate of timing coding is $42 \%$, and that of industry choice coding is $50 \%$ ). Yet, the sum of the three-coder-agreement rate and the two-coder-agreement rate of the motivation coding about the 140 papers is up to $83 \%$. Therefore, the reliability of data coding is acceptable as a whole. All those items that were ambiguous or on which the coders couldn't reach agreement through discussion were deleted, thus all the retained items gained agreement of 
the president and the three coders. The information about the change in the item number is showed in Table 5.

Table 4 Summary of agreement rate in coding and factor analysis

\begin{tabular}{|c|c|c|c|c|c|c|}
\hline & & & Sam & ple I & Sam & e II \\
\hline & & & $\begin{array}{l}\text { 3-coder- } \\
\text { agreement } \\
(\%)\end{array}$ & $\begin{array}{l}\text { 2-coder- } \\
\text { agreement } \\
\quad(\%)\end{array}$ & $\begin{array}{l}\text { 3-coder- } \\
\text { agreement } \\
(\%)\end{array}$ & $\begin{array}{l}\text { 2-coder- } \\
\text { agreement } \\
\quad(\%)\end{array}$ \\
\hline Qualitative & & Motivation & 55 & 28 & 25 & 35 \\
\hline open & & Timing & 9 & 33 & 29 & 38 \\
\hline coding & & Industry choice & 31 & 19 & 34 & 31 \\
\hline Qualitative & Step 1 & Motivation & 64 & 28 & 39 & 44 \\
\hline factor & & Timing & 93 & 4 & 98 & 2 \\
\hline analysis & & Industry choice & 100 & & 94 & 6 \\
\hline & Step 2 & Motivation & 46 & 38 & 50 & 48 \\
\hline & & Timing & 61 & 39 & 51 & 43 \\
\hline & & Industry choice & 53 & 30 & 64 & 35 \\
\hline
\end{tabular}

Table 5 Summary of the numbers of the items in coding and factor analysis

\begin{tabular}{lllcc}
\hline & & Sample I & Sample II \\
\hline Qualitative open coding & & Motivation & 369 & 126 \\
& & Timing & 46 & 95 \\
Qualitative factor analysis & Step 1 & Industry choice & 52 & 107 \\
& & Motivation & $345(-24)$ & $126(0)$ \\
& & Timing & $45(-1)$ & $91(-4)$ \\
& \multirow{2}{*}{ Step 2 } & Industry choice & $50(-2)$ & $107(0)$ \\
& & Motivation & $353(+8)$ & $124(-2)$ \\
& & Timing & $46(+1)$ & $90(-1)$ \\
& Industry choice & $43(-7)$ & $100(-7)$ \\
\hline
\end{tabular}

Notes: The numbers in ( ) mean the numbers of the terms we added to or deleted from the terms lists after discussion. For example, in "motivation" of "Sample I" we read $345(-24)$, which means that $369-24=345$. In other words, the number before discussion was 369 , and the number after discussion was 345 . We deleted 24 ambiguous terms through discussion.

\subsection{Qualitative factor analysis}

This is a process similar to the factor analysis in quantitative research. The process includes three steps (Eisenhardt, 1989). The first step is to sort the original data into major categories, guided by an initial general theoretical framework. The second step is to identify subcategories in each major category. The third step is to give a label for each subcategory. The purpose of the qualitative factor analysis 
is to identify themes from a large volume of qualitative data, i.e., to reduce the data and identify the construction of the data.

Step 1: sorting the terms of motivation, timing and industry choice into major categories guided by the initial theoretical framework respectively

Three authors sorted the items in double-blind fashion according to the meaning of each item. For the motivation items, we used six major categories suggested mainly by Hoskisson and Hitt (1990). The six categories are resource-based theory (RBT), portfolio theory (PT), agency theory (AT), transaction cost theory (TCT), government policy (GP), and institutional theory (IT). For the timing items, we employed four major categories based on SWOT analysis. The four categories are strength $(\mathrm{S})$, weakness $(\mathrm{W})$, opportunity $(\mathrm{O})$ and threat $(\mathrm{T})$. For the industry choice items, we utilized two major categories suggested by Porter (1985), which are interrelationship and attractiveness. What cannot be sorted into the above-mentioned categories is sorted into an additional category named "other."

After summarizing the sorting results, the research head and the three coders discussed the items without consensus of sorting. The agreement rates of the sorting before discussion are showed in Table 4. We can learn from Table 4 that the sum of the three-coder-agreement rate and the two-coder-agreement rate ranges from $83 \%$ to $100 \%$, so the sorting reliability is quite high. All those items that were ambiguous or could not reach agreement through discussion were deleted. The information about the change in the item number is shown in Table 5.

Step 2: sorting the items in each major category into subcategories

The next step of sorting is to identify subcategories for each of the major categories. Each of the three authors independently sorted the items in each major category into subcategories according to the similarity of the meaning of each item. The agreement rates of sorting before discussion are shown in Table 4. We learn from the table that the sums of the three-coder-agreement and the two-coder-agreement rate for each sample are above $83 \%$, most of which ranges from $90 \%$ to $100 \%$. Thus, the sorting reliability is quite high. Similar to Step 1, all those items that were ambiguous or could not reach agreement through discussion were deleted. The information about the change in the item number is showed in Table 5.

Step 3: labeling each subcategory

Three authors independently selected a representative statement for each subcategory, using the most frequently mentioned item in the subcategory. After summarizing the results of the three coders, the research head discussed with the three coders the labeling of each subcategory, and eliminated those subcategories that consisted of only one item. The final results of the qualitative open coding and the qualitative factor analysis are shown in Table 6, 7 and 8. 
Table 6 The dimensions of the motivation of diversification of Western theories and Chinese enterprises

Sample I

Sample II

Western theories (345)

Chinese CEOs (119)

\section{Resource-based theory (193)}

To efficiently utilize tangible resources, such as distribution systems, technologies, manufacturing facilities, and excess cash flows (38)

To efficiently utilize intangible resources, such as managerial capabilities and experiences, control systems, marketing capabilities and experience (50)

To obtain economies of scale (18)

To exploit economies of scope (35)

To lower costs, such as fixed costs, wage cost, transport cost and the cost of capital (8)

To discourage potential rivals or subvert competitive forces through mechanisms such as cross-subsidization, predatory pricing, reciprocity in selling and buying, barriers to entry (7)

To enhance the firm's market power and competitive position (26)

To obtain and expand the firm's resources (11)

\section{Portfolio theory (102)}

To widen and exploit market opportunities (13)

To reduce risks (35)

To increase the firm's profitability (11)

To offset the firm's weaknesses and get over their poor performance (8)

To adapt to the environmental uncertainty, such as changes in supply and demand, technology, capital market, industry structure (20)

To reduce the revenue variance (15)

\section{Resource-based theory (56)}

To exploit the firm's tangible resources, i.e., cash flows, human resources, distribution (16)

To exploit the firm's intangible resources, i.e., brand names, management experience (12)

To exploit economies of scale (18)

To extend the industry chain (7)

To acquire important resources (3)

\section{Portfolio theory (58)}

To widen and exploit market opportunities (13)

To reduce risks (11)

To acquire profits $(8)$

To offset firm's weaknesses, including internal difficulties and external restrictions (8)

To realize the complementary development between industries (9)

To optimize the industry distribution and stabilize the firm's position (9)

\section{Agency theory (17)}

To increase managerial benefits, such as reducing managerial employment risk and increasing managerial compensation and status (17) 
(Continued)

Sample I

Western theories (345)
Sample II

Chinese CEOs (119)

\section{Transaction cost theory (26)}

To benefit from an internal capital market (9)

To get over market failure and lower

transaction costs (10)

To benefit from information asymmetry (4)

To gain integration economies (3)

\section{Government policy (7)}

To acquire tax benefits (5)

To evade important restrictions (2)

Others (2)

To internationalize the firm (2)

Notes: The numbers in parentheses are the numbers of items included in the major categories or subcategories, and the phrases are the labels of the major categories or subcategories. For the data of Sample I of the 140 papers, the same viewpoints put forward by the same author in each paper were coded only once; for the data of Sample II, i.e., the 30 CEOs' public statements, the same viewpoints appearing in the same case were coded only once.

\section{Results and comparison}

5.1 Analysis on the similarities and differences between Western theories and the cognition of Chinese enterprises on the motivation of diversification

Firstly, the contingency table (see Table 9) was calculated according to Table 6. Secondly, the Chi-square similarity values (see Table 10) were calculated from Table 9.

The main similarity between the cognition of Western theories and Chinese enterprises on the motivation of diversification is that they both view it mainly from the perspectives of the resource-based view and asset portfolio theory. Such similarity is obviously shown in Table 9 where the percentages in each sample are 55.9, 47.1 and 29.6, 48.1, respectively. The total percentage of the two perspectives of RBV and PT is 88.2.

As the detailed contents show in Table 6, the cognitive similarities between Western theories and Chinese enterprises on the motivation of diversification in the perspectives of the resource-based theory and portfolio theory are salient. From the perspective of the resource-based theory, they both emphasize much that firms diversify to exploit their tangible and intangible resources, to realize scale 
Table 7 The dimensions of the timing of diversification of Western theories and Chinese enterprises

\begin{tabular}{|c|c|}
\hline $\begin{array}{l}\text { Sample I } \\
\text { Western theories (36) }\end{array}$ & $\begin{array}{c}\text { Sample II } \\
\text { Chinese CEOs (88) }\end{array}$ \\
\hline Strength(6) & Strength (56) \\
\hline $\begin{array}{l}\text { When the firm has excess tangible } \\
\text { resources, such as physical capacity, } \\
\text { cash flows, and technological } \\
\text { resources (4) }\end{array}$ & $\begin{array}{l}\text { When the firm has enough tangible resources, } \\
\text { such as human resources, cash flows, } \\
\text { technology and market networks (27) }\end{array}$ \\
\hline $\begin{array}{l}\text { When the firm has appropriate intangible } \\
\text { resources, such as experience in } \\
\text { technologies and decentralized } \\
\text { structure (2) }\end{array}$ & $\begin{array}{l}\text { When the firm has enough intangible resources, } \\
\text { such as management capabilities and } \\
\text { experience, corporation cultures, and brand } \\
\text { names (12) } \\
\text { When the core business is operated } \\
\text { successfully (14) } \\
\text { When the production capability of the core } \\
\text { business exceeds the demand of the } \\
\text { market (3) }\end{array}$ \\
\hline
\end{tabular}

\section{Weakness (5)}

When the operation of the core business is not successful, for example, the brand name is not famous, or the profit is not high (3)

When the operation of the core business has difficulty(2)

\section{Opportunities (4)}

\section{Opportunities (7)}

when environmental uncertainties

decreases (2)

when markets are growing (2)

When the potentiality of the new industry is large (4)

When the growing economy gives opportunities to the new industry (3)

\section{Threats (26)}

When there is limited potential in the firm's present markets (16)

When the firm's own business become more risky (3)

When the demand conditions in original markets have changed and become uncertain (2)

\section{Threats (20)}

When the present markets have declined and lack potential (11)

When the competition in present markets is fierce (5)

When the present business has high risks and is unstable (2)

When the present business is restricted by the business environment (2) 
(Continued)

\begin{tabular}{lc}
\hline $\begin{array}{l}\text { Sample I } \\
\text { Western theories (36) }\end{array}$ & $\begin{array}{c}\text { Sample II } \\
\text { Chinese CEOs (88) }\end{array}$ \\
\hline $\begin{array}{l}\text { When the technology conditions in } \\
\text { original markets have changed and }\end{array}$ \\
become uncertain (3) \\
$\begin{array}{l}\text { When the core industry is regulated, for } \\
\text { example, by anti-trust enforcement (2) }\end{array}$ \\
\hline
\end{tabular}

Notes: The numbers in parentheses are the numbers of items included in the major categories or subcategories, and the phrases are the labels of the major categories or subcategories. For the data of Sample I involving the 140 papers, the same viewpoints put forward by the same author in each paper were coded only once; for the data of Sample II, i.e., the 30 CEOs' public statements, the same viewpoints appearing in the same case were coded only once.

and scope economies, to lower costs, and to acquire resources. And from the perspective of the asset portfolio theory, they both argue that firms diversify to exploit market opportunities, to lower operation risks, to acquire profits, to adapt to changes and restrictions, and to stabilize revenues.

As shown in Table 9 and 10, however, the cognitive differences between Western theories and Chinese enterprises on the motivation of diversification are also obvious. For Sample I, Western theories emphasize the factors pertinent to the resource-based theory, agency theory, transaction cost theory and government policies (the Chi-square similarity values are $0.33,1.5,0.91$ and 0.62 , respectively). For Sample II, Chinese CEOs pay more attention to the factors related to the portfolio theory (the Chi-square similarity value is 7.01). In Table 10, although the factor denoting "others" is strongly related to Sample II (the Chi-square similarity value is 4.31) for there are only 2 items in this subcategory, we ignore this factor in our discussion. Therefore, the overview of the differences between the cognition of Western theories and that of Chinese enterprises on the motivation of diversification can reach a conclusion that the former emphasizes the motivation factors related to the resource-based theory, agency theory, transaction cost theory and government policies, while the latter thinks much of the factors relevant to the portfolio theory. The total difference is distinct with the Chi-square of $28.372(d f=5, p=0.000)$ and Cramer's $V$ of $0.247(p=0.000)$.

5.2 Analysis on the similarities and differences between the cognition of Western theories and that of Chinese enterprises on the timing of diversification

The methods of calculating the contingency (Table 11) and the Chi-square similarity values (Table 12) are the same as above. The cognition on the timing of 
Table 8 The dimensions of the industry choice on diversification of western theories and Chinese enterprises

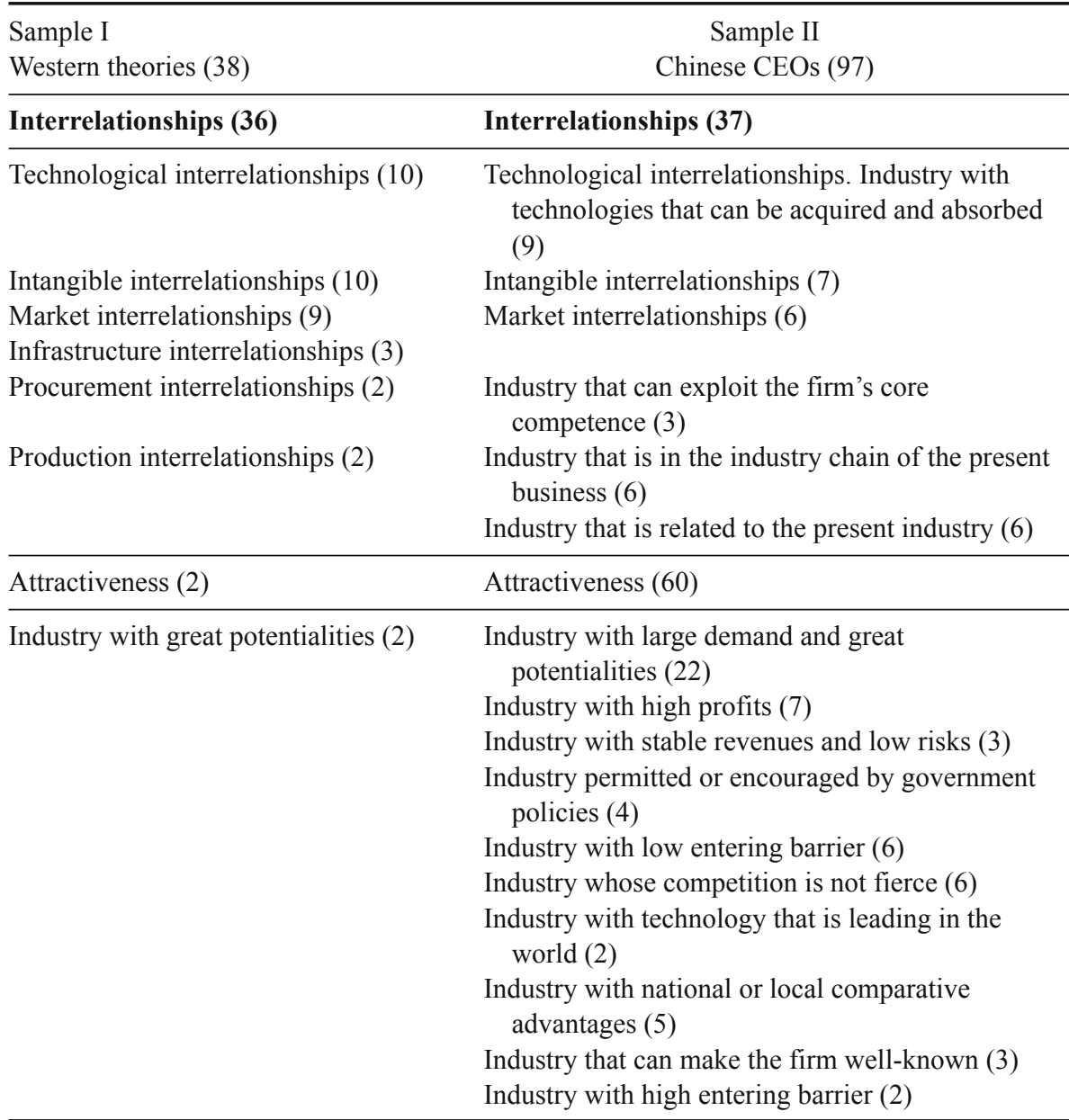

Notes: The numbers in parentheses are the numbers of items included in the major categories or subcategories, and the phrases are the labels of the major categories or subcategories. For the data of Sample I involving the 140 papers, the same viewpoints put forward by the same author in each paper were coded only once; for the data of Sample II, i.e., the 30 CEOs' public statements, the same viewpoints appearing in the same case were coded only once.

diversification between Western theories and Chinese enterprises is remarkably different except that they both pay more attention to the opportunity of diversification (the percentages of opportunities are 11.11 and 7.95 , respectively in Table 11; and the Chi-square similarity values are 0.2 and -0.08 , respectively in Table 12, which are near zero). 
Table 9 Contingency table of diversification motivations and samples

\begin{tabular}{|c|c|c|c|c|c|c|c|c|}
\hline & & \multicolumn{7}{|c|}{ Diversification motivations } \\
\hline & & RBT & PT & AT & TCT & GP & Others & Total \\
\hline \multirow[t]{4}{*}{ Samples } & Sample I & 193 & 102 & 17 & 26 & 7 & 0 & 345 \\
\hline & & $55.9 \%$ & $29.6 \%$ & $4.9 \%$ & $7.5 \%$ & $2.0 \%$ & $0.0 \%$ & $100.0 \%$ \\
\hline & Sample II & 56 & 58 & 0 & 3 & 0 & 2 & 119 \\
\hline & & $47.1 \%$ & $48.7 \%$ & $0.0 \%$ & $2.5 \%$ & $0.0 \%$ & $1.7 \%$ & $100.0 \%$ \\
\hline \multirow[t]{2}{*}{ Total } & & 249 & 160 & 17 & 29 & 7 & 2 & 464 \\
\hline & & $53.7 \%$ & $34.5 \%$ & $3.7 \%$ & $6.3 \%$ & $1.5 \%$ & $0.4 \%$ & $100.0 \%$ \\
\hline
\end{tabular}

Notes: $\chi^{2}=28.372(d f=5, p=0.000)$, Cramer's $V=0.247(p=0.000)$.

Table 10 Chi-Square similarity values for Table 9

\begin{tabular}{llcccccc}
\hline & \multicolumn{6}{c}{ Diversification motivations } \\
\cline { 3 - 8 } & & RBT & PT & AT & TCT & GP & Others \\
\hline \multirow{2}{*}{ Samples } & Sample I & 0.33 & -2.4 & 1.5 & 0.91 & 0.62 & -1.5 \\
& Sample II & -1 & 7.01 & -4.4 & -2.7 & -1.8 & 4.31 \\
\hline
\end{tabular}

Notes: Negative values indicate low association (similarity) and positive values indicate greater association. For example, in the row of Sample II, 7.01 and 4.31 indicate high association between PT, others and Sample II.

Table 11 Contingency table of diversification timing and samples

\begin{tabular}{lllllll}
\hline & \multicolumn{5}{c}{ Diversification timing } \\
\cline { 3 - 7 } & & Strength & Weakness & Opportunity & Threat & Total \\
\hline Samples & Sample I & 6 & 0 & 4 & 26 & 36 \\
& & $16.67 \%$ & $0.00 \%$ & $11.11 \%$ & $72.22 \%$ & $100.00 \%$ \\
& Sample II & 56 & 5 & 7 & 20 & 88 \\
Total & $63.64 \%$ & $5.68 \%$ & $7.95 \%$ & $22.73 \%$ & $100.00 \%$ \\
& & 62 & 5 & 11 & 46 & 124 \\
& $50.00 \%$ & $4.03 \%$ & $8.87 \%$ & $37.10 \%$ & $100.00 \%$ \\
\hline
\end{tabular}

Notes: $\chi^{2}=30.476(d f=3, p=0.000)$, Cramer's $V=0.496(p=0.000)$.

Table 12 Chi-Square similarity values for Table 11

\begin{tabular}{llcccr}
\hline & \multicolumn{4}{c}{ Diversification timing } \\
\cline { 3 - 6 } & & Strength & Weakness & Opportunity & Threat \\
\hline \multirow{2}{*}{ Samples } & Sample I & -8.00 & -1.45 & 0.20 & 12.00 \\
& Sample II & 3.27 & 0.59 & -0.08 & -4.90 \\
\hline
\end{tabular}

Notes: Negative values indicate low association (similarity) and positive values indicate greater association. For example, in the row of Sample II, 3.27 indicates high association between strength and Sample II. 
As showed in Table 12, Sample I of Western theories emphasizes the factors of threats (the Chi-square similarity value is 12), while Sample II of Chinese CEOs pays more attention to strengths and weaknesses (the Chi-square similarity values are 3.27 and 0.59 respectively). The total difference was distinct with the Chi-square of $30.476(d f=3, p=0.0000)$ and Cramer's $V$ of $0.496(p=0.000)$.

5.3 Analysis on the similarities and differences between the cognition of Western theories and that of Chinese enterprises on the industry choice of diversification

Table 13 and Table 14 are calculated in the same way as above.

Table 13 Contingency table of industry choice and samples

\begin{tabular}{lcccc}
\hline & & \multicolumn{3}{c}{ Industry choice } \\
\cline { 3 - 5 } & & Interrelationship & Attractiveness & Total \\
\hline Samples & Sample I & 36 & 2 & 38 \\
& & $94.7 \%$ & $5.3 \%$ & $100.0 \%$ \\
& Sample II & 37 & 60 & 97 \\
\multirow{3}{*}{ Total } & & $68.1 \%$ & 62 & $100.0 \%$ \\
& & 73 & $45.9 \%$ & 135 \\
& & $54.1 \%$ & $100.0 \%$ \\
\hline
\end{tabular}

Notes: $\chi^{2}=35.212(d f=1, p=0.000)$, Cramer's $V=0.511(p=0.000)$.

Table 14 Chi-Square similarity values for Table 13

\begin{tabular}{llcc}
\hline & \multicolumn{2}{c}{ Industry choice } \\
\cline { 3 - 4 } & & Interrelationship & Attractiveness \\
\hline \multirow{2}{*}{ Samples } & Sample I & 11.62 & -13.68 \\
& Sample II & -4.55 & 5.36 \\
\hline
\end{tabular}

Notes: Negative values indicate low association (similarity) and positive values indicate greater association. For example, in the row of Sample I, 11.62 indicates high association between interrelationship and Sample I.

As shown in Tables 13 and 14, Sample I of Western theories emphasizes the factors of interrelationship (the Chi-square similarity value is 11.62); Sample II of Chinese CEOs pays more attention to attractiveness (the Chi-square similarity value is 5.68 ).

As the detailed contents shown in Table 8, in addition to technological, intangible and market interrelationships emphasized by Western theories, Chinese enterprises lay more emphasis on resource-sharing, business relatedness and similarities, and business complementariness. Therefore, in the overview of the 
similarities and differences between the cognition of Western theories and that of Chinese enterprises on the industry choice of diversification, it can be concluded that the former remarkably focuses on the interrelationships between the original industries and the intended industries, while the latter pays more attention to attractiveness than interrelationships. Nevertheless, Chinese enterprises comparatively seek balance between the interrelationship and attractiveness than Western theories do. The total difference is distinct with the Chi-square of 35.212 $(d f=1, p=0.000)$ and Cramer's $V$ of $0.511(p=0.000)$.

\section{Conclusions and discussions}

Why, when, and how to diversify? Is the cognition of Chinese enterprises on these different from that of Western theories? In this exploratory study, two different samples were selected, including 140 papers published in the top Western journals, and the public statements of 30 influential CEOs in China. Both the qualitative open coding and the qualitative factor analysis were employed in the data of the two samples respectively, and then the corresponding analysis was utilized to find out the similarities and differences between the cognition of Western theories and that of Chinese enterprises on the motivation, timing and industry choice of enterprises' diversification.

Firstly, the main cognitive similarity between Western theories and Chinese enterprises on the motivation of diversification is that they both consider the diversification motivation mainly from the perspectives of the resource-based view and asset portfolio theory. The main cognitive difference between them is that Western theories emphasize the motivation factors related to resource-based theory, agency theory, transaction cost theory and government policies, while Chinese enterprises consider more of the factors relevant to portfolio theory.

Secondly, the cognitive difference on the timing of diversification between Western theories and Chinese enterprises is distinct. Western theories emphasize that firms diversify when they meet threats, while Chinese enterprises stress that firms diversify when they have enough strengths or some weaknesses.

Thirdly, the cognitive difference on the industry choice of diversification between Western theories and Chinese enterprises is significant, too. Western theories remarkably emphasize the interrelationships between the original industries and the intended industries, while Chinese enterprises pay more attention to attractiveness than interrelationship.

Some interesting and meaningful questions should be studied further, which are brought forward by the cognitive similarities and differences on the timing and industry choice of diversification between Western theories and Chinese enterprises. 
Firstly, if the causal relationship between motivation and industry choice is made on the basis of the holistic model given by Hoskisson and Hitt (1990), the different relationships are set. Western theories that emphasize the factors related to the resource-based theory, agency theory, transaction cost theory and government policies prefer the industries with interrelationships to those with attractiveness. However, Chinese enterprises that stress the factors pertinent to the portfolio theory seek the industries with more attractiveness than interrelationships. Does such a relationship have any theoretical logic? If there is, can the relationship be empirically supported?

Secondly, Western theories emphasize that companies are diversified when they meet threats, and they think of the motivation of diversification from the perspectives of resource-based theory, agency theory, transaction cost theory and government policies. However, Chinese enterprises stress that firms diversify when they have enough strengths, and they consider the motivation of diversification from the perspective of the portfolio theory. Does the relationship between timing and motivation have any theoretical logic? If there is, can the relationships be empirically supported?

Seeking the answers to such questions may not only enrich the knowledge of diversification under the Chinese context, but also improve the holistic model of current researches on diversification. Such work is significant and full of challenges.

Acknowledgements We gratefully acknowledge the supervision of Professor Anne S. Tsui on the research methodology. We are also grateful for the support from the National Natural Science Foundation of China (Grant No. 70572049) and from the Center for Economic Transition, Development and Innovation of Nanjing University of National "985 Project."

\section{References}

Amihud Y, Lev B (1999). Does corporate ownership structure affect its strategy towards diversification? Strategic Management Journal, 20(11): 1063-1069

Amihud Y, Lev B (1981). Risk reduction as a managerial motive for conglomerate mergers. Bell Journal of Economics, (12): 605-617

Andrews K R (1971). The Concept of Corporate Strategy. Homewood, IL: Dow Jones-Irwin

Ansoff H I (1965). Corporate Strategy: An Analytic Approach to Business Policy for Growth and Expansion. New York: McGraw-Hill

Anthony R N (1965). Planning and Control System: A Framework for Analysis. Cambridge, MA: Harvard Business School

Chatterjee S, Wernerfelt B (1991). The link between resources and type of diversification: Theory and evidence. Strategic Management Journal, 12(1): 33-48

Eisenhardt K M (1989). Building theories from case study research. Academy of Management Review, 14(4): 532-550 
Farjoun M (1998). The independent and joint effects of the skill and physical bases of relatedness in diversification. Strategic Management Journal, 19(7): 611-630

Goulding C (2002). Grounded Theory: A Practical Guide for Management, Business and Market Researchers. London: Sage Publications Ltd

Guthrie D (1997). Between markets and politics: Organizational responses to reform in China. American Journal of Sociology, (102): 1258-1304

Hamel G (1994). The Concept of Core Competence. In: Hamel G, Heene A, eds. Competence-based Competition. Chichester: John Wiley \& Sons

Hoskisson R E, Hitt M A (1990). Antecedents and performance outcomes of diversification: A Review and Critique of Theoretical Perspectives. Journal of Management, 16(2): 461-509

Jensen M, Meckling W (1976). Theory of the firm: Managerial behavior, agency costs and ownership structure. Journal of Financial Economics, (3): 305-360

Khanna T, Palepu K (1997). Why focused strategies may be wrong for emerging markets. Harvard Business Review, 75(4): 41-51

Kochhar R, Hitt M A (1998). Linking corporate strategy to capital structure: Diversification strategy, Type and Source of Financing. Strategic Management Journal, 19(6): 601-610

Lane P J, Cannella A A Jr, Lubatkin M H (1998). Agency problems as antecedents to unrelated mergers and diversification: Amihud and Lev reconsidered. Strategic Management Journal, 19(6): 555-578

Li Mingfang, Wong Yim-Yu (2003). Diversification and economic performance: An empirical assessment of Chinese firms. Asia Pacific Journal of Management (in Chinese), (20): 243-265

Lubatkin M, Chatterjee S (1994). Extending modern portfolio theory into the domain of corporate diversification: Does it apply? Academy of Management Journal, 37(1): $109-136$

Markham J W (1973). Conglomerate Enterprises and Public Policy. Boston, MA: Harvard Business School

Markides C C (1995). Diversification, restructuring and economic performance. Strategic Management Journal, 16(2): 101-118

Penrose E T (1995). The Theory of the Growth of the Firm (3 $3^{\text {rd }}$ edition). Oxford: Oxford University Press

Porter M E (1985). Competitive Advantage. New York: The Free Press

Porter M E (1980). Competitive Strategy. New York: The Free Press

Ravenscraft D J, Scherer R M (1987). Mergers, Sell-offs and Economic Efficiency. Washington, DC: The Brookings Institution

Rose N L, Shepard A (1997). Firm diversification and CEO compensation: Managerial ability or executive entrenchment? Rand Journal of Economics, 28(3): 489-514

Rumelt R P (1974). Strategy, Structure, and Economic Performance. Cambridge, MA: Harvard University Press

Simmonds P G (1990). The combined diversification breadth and mode dimensions and the performance of large diversified firms. Strategic Management Journal, 11(5): 399-410

Strauss A, Corbin J (1998). Basics of Qualitative Research: Techniques and Procedures for Developing Grounded Theory ( $2^{\text {nd }}$ edition). Thousand Oaks: Sage Publications

Wernerfelt B (1984). A resource based view of the firm. Strategic Management Journal, 5(2): $171-80$

Williamson O E (1975). Markets and Hierarchies. New York: Free Press

Yao Jun, Lü Yuan and Lan Hailin (2004). An empirical study of the relationship between diversification of China's listed companies and the economic performance. Management World (in Chinese), (11): 119-125 


\section{Appendix 1 The authors and source journals of 140 papers (Sample I)}

Christensen \& Montgomery, 1981, SMJ

Bettis, 1981, SMJ

Rumelt, 1982, SMJ

Montgomery, 1982, AMJ

Bettis \& Hall, 1982, AMJ

Montgomery, 1985, AMJ

Palepu, 1985, SMJ

Bettis \& Mahajan, 1985, MS

Silhan \& Thomas, 1986, SMJ

Reed \& Luffman, 1986, SMJ

Montgomery \& Wilson, 1986, SMJ

McGee \& Thomas, 1986, SMJ

Fahey \& Christensen, 1986, $J M$

Prahalad \& Bettis, 1986, SMJ

Porter, 1987, HBR

Napier \& Smith, 1987, SMJ

Johnson \& Thomas, 1987, SMJ

Hopkins, 1987, JM

Hopkins, 1987, SMJ

Dubofsky \& Varadarajan, 1987, AMJ

Buhner, 1987, SMJ

Williams, Paez \& Sanders, 1988, SMJ

Smith \& Cooper, 1988, SMJ

Keats \& Hitt, 1988, AMJ

Jones \& Hill, 1988, SMJ

Hoskisson \& Hitt, 1988, SMJ
Hill \& Snell, 1988, SMJ

Nayyar, 1990, SMJ

Grinyer, McKiernan \& Yasai-Ardekani, 1988, SMJ

Grant \& Jammine, 1988, SMJ Hoskisson \& Turk, 1990, AMR

Grant, Jammine \& Thomas, 1988, AMJ

Grant, 1988, SMJ

Capon, Hulbert, Farley \& Martin, 1988, SMJ

Balakrishnan, 1988, SMJ

Amit \& Livnat, 1988, SMJ

Reed \& Reed, 1989, JMS

Ramanujam \& Varadarajan, 1989, SMJ

Nayyar, McGee \& Thomas, 1989, SMJ

Hoskisson \& Hitt, 1990, JM

Hitt, Hoskisson \& Ireland, 1990, SMJ

Ginsberg, 1990, AMR

Fryxell \& Barton, 1990, JM

Fombrun \& Ginsberg, 1990, SMJ

Dess, Ireland \& Hitt, 1990, $J M$

Chatterjee \& Lubatkin, 1990, $S M J$

Schleifer \& Vishny, 1991, SMJ

Russo, 1991, AMJ $A M J$

Kim, Hwang \& Burgers, 1989, SMJ

Ginsberg, 1989, JMS

Lubatkin \& Chatterjee, 1991, SMJ

Hoskisson, Harrison \& Dubofsky, 1991, SMJ

Geringer, Beamish \& daCosta, Hill \& Hansen, 1991, SMJ 1989, SMJ

Chang \& Thomas, 1989, SMJ Datta, Rajagopalan \& Rasheed, 1991, JMS

Baysinger \& Hoskisson, 1989, Chatterjee \& Wernerfelt, $A M J$ 1991, SMJ

Varadarajan \& Ramanujam, Rumelt, 1991, SMJ $1990, J M S$

Simmonds, 1990, SMJ

Seth, 1990, SMJ

Wiersema \& Bantel, 1992, AMJ

Russo, 1992, SMJ

Nguyen, Seror \& Devinney, 1990, SMJ

Nayyar, 1992, SMJ

Lundquist, 1992, HBR

Judge \& Zeithaml, 1992, AMJ

Hoskisson \& Johnson, 1992, SMJ

Gomez-Mejia, 1992, SMJ

Davis \& Duhaime, 1992, $S M J$ 
(Continued)

Chatterjee \& Blocher, 1992,
AMJ

Amburgey \& Miner, 1992, SMJ

Seth \& Easterwood, 1993, SMJ

Nayyar \& Kazanjian, 1993, $A M R$

Nayyar, 1993, SMJ

Miles, Snow \& Sharfman, 1993, SMJ

Lubatkin, Merchant \& Srinivasan, 1993, SMJ

Kim, Hwang \& Burgers, 1993, SMJ

Hoskisson, Hitt, Johnson \& Moesel, 1993, SMJ

Hoskisson, Hill \& Kim, 1993, JM

Harrison, Hall \& Nargundkar, 1993, AMJ

Ollinger, 1994, SMJ

Lubatkin \& Chatterjee, 1994, AMJ

Lamont, Williams \& Hoffman, 1994, AMJ

Mitchell, Shaver \& Yeung, 1994, SMJ

Markides \& Williamson, 1994, SMJ

Koch \& Cebula, 1994, JMS

Kashlak \& Joshi, 1994, SMJ

Ito \& Rose, 1994, SMJ

Ingham \& Thompson, 1994, SMJ

Hitt, Hoskisson \& Ireland,
Hall \& St John, 1995, SMJ

Buchko, 1994, AMJ

Wiersema \& Liebeskind, 1995, SMJ

Robins \& Wiersema, 1995, SMJ

Markides, 1995, SMJ

Li, 1995, SMJ

Ito, 1995, SMJ

Campbell, Goold \& Alexander, 1995, $H B R$

Bettis \& Prahalad, 1996, SMJ Anand \& Singh, 1997, SMJ

Tallman \& Li, 1996, AMJ

Lane, Cannella \& Lubatkin, $1998, S M J$

Sharma \& Kesner, 1996, AMJ Kochhar \& Hitt, 1998, SMJ

Sambharya, 1996, SMJ

Markides \& Williamson, 1996, AMJ

Farjoun, 1998, SMJ

Bethel \& Liebeskind, 1998, OS

Lubatkin \& Lane, 1996, AME Bergh \& Lawless, 1998, OS

Lei, Hitt \& Bettis, 1996, JM

Kim \& Kogut, 1996, OS

Chen, 1996, JMS

Chang, 1996, SMJ

Carroll, Seidel \& Tsai, 1996, SMJ

Brush, 1996, SMJ

Argyres, 1996, SMJ

Anslinger \& Copeland, 1996, $H B R$

Stimpert \& Duhaime, 1997, $S M J$

Stimpert \& Duhaime, 1997, $A M J$

Rowe \& Wright, 1997, SMJ

Merino \& Rodriguez, 1997, SMJ

Notes: $S M J=$ Strategic Management Journal; AMJ = Academy of Management Journal; $J M=$ Journal of Management; JMS = Journal of Management Studies; HBR = Harvard Business Review; AMR = Academy of Management Review; OS = Organization Science; $A M E=$ Academy of Management Executive; $M S=$ Management Science; RJE = Rand Journal of Economics. 